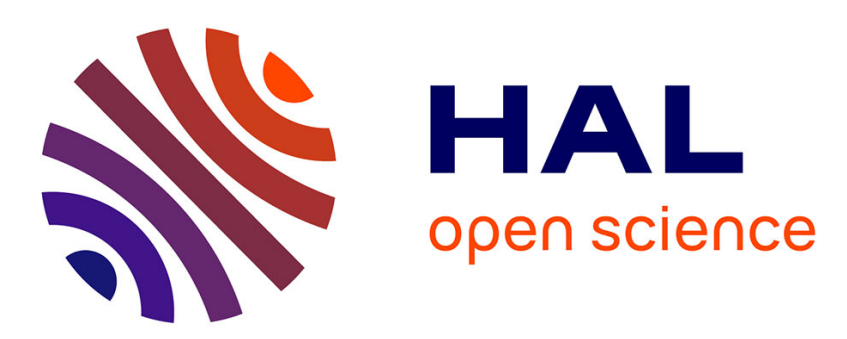

\title{
Numerical modeling of the 26 November 1999 Vanuatu tsunami
}

\author{
M. Ioualalen, B. Pelletier, P. Watts, M. Régnier
}

\section{To cite this version:}

M. Ioualalen, B. Pelletier, P. Watts, M. Régnier. Numerical modeling of the 26 November 1999 Vanuatu tsunami. Journal of Geophysical Research, 2006, 111 (C6), 13 pp. 10.1029/2005JC003249 . hal-00407598

\section{HAL Id: hal-00407598 \\ https://hal.science/hal-00407598}

Submitted on 20 Aug 2021

HAL is a multi-disciplinary open access archive for the deposit and dissemination of scientific research documents, whether they are published or not. The documents may come from teaching and research institutions in France or abroad, or from public or private research centers.
L'archive ouverte pluridisciplinaire HAL, est destinée au dépôt et à la diffusion de documents scientifiques de niveau recherche, publiés ou non, émanant des établissements d'enseignement et de recherche français ou étrangers, des laboratoires publics ou privés. 


\title{
Numerical modeling of the 26 November 1999 Vanuatu tsunami
}

\author{
M. Ioualalen, ${ }^{1}$ B. Pelletier, ${ }^{2}$ P. Watts, ${ }^{3}$ and M. Regnier ${ }^{4}$ \\ Received 25 August 2005; revised 11 January 2006; accepted 13 March 2006; published 21 June 2006.
}

[1] On 26 November 1999, at 1321 UT, central Vanuatu was struck by a large offshore earthquake $\left(M_{w} 7.5\right)$ followed by a tsunami that killed five people and caused significant damage to nearshore structures, mainly at Martelli Bay, south Pentecost Island. The tsunami is simulated using the Geowave model. The Tsunami Open and Progressive Initial Conditions System (TOPICS) source component of the model simulates the initial water column deformation, and the propagation and runup are simulated with the FUNWAVE fully nonlinear Boussinesq and dispersive model. A special effort was made on the construction of the computational grid through comprehensive bathymetry data sets obtained especially from two multibeam bathymetric surveys performed after the earthquake and tsunami. Three different tsunami sources have been considered. The first one is the fault rupture itself, the second is a landslide located east of Ambrym Island, and the third source is a submarine structure within the Selwyn Strait that will be considered as a landslide, however, with a large uncertainty because it could be a result of lava deposit as well. It is found that the earthquake-derived tsunami source fits most of the postsurvey observations, in particular the overall wave amplitudes (up to 6-7 m observed and simulated). The timing of the tsunami is also satisfactory when objective interpretation of the eyewitnesses is processed. Thus it is found that the hypothetical landslide-derived tsunami contributions are not necessary to predict the tsunami. This is because they do not help in the tsunami timing but also because their wave amplitude contributions are one order of magnitude lower than that of the earthquake source.

Citation: Ioualalen, M., B. Pelletier, P. Watts, and M. Regnier (2006), Numerical modeling of the 26 November 1999 Vanuatu tsunami, J. Geophys. Res., 111, C06030, doi:10.1029/2005JC003249.

\section{Introducing the 26 November 1999 Vanuatu Tsunami}

[2] On 26 November 1999, at 1321 UT, central Vanuatu (Figure 1) was struck by a large offshore earthquake $\left(M_{w}\right.$ 7.5) followed by a tsunami that killed 5 people and caused important damages in nearshore structures. That was the most damaging earthquake in central Vanuatu since the $M_{w}$ 7.1 event in Santo in October 1971. The observations of the posttsunami surveys, conducted by the Institut de Recherche pour le Développement (IRD) and the Department of Geology, Mines and Water Resources of Vanuatu (B. Pelletier, J. M. Bore, and others) first in south Pentecost and then in east Ambrym (from 11 to 14 December) and by an International Tsunami Survey Team (C. Synolakis, H. Matsutomi, and others) in south Pentecost, north Ambrym, east Malakula, Santo and Efate (from 15 to 19 December) are reported

\footnotetext{
${ }^{1}$ Institut de Recherche pour le Développement, UR082/UMR Géosciences Azur, l'Observatoire Océanologique de Villefranche-sur-mer, Villefranche-sur-mer, France.

${ }^{2}$ Institut de Recherche pour le Développement, UR082/UMR Géosciences Azur, Nouméa, New Caledonia.

${ }^{3}$ Applied Fluids Engineering, Inc., Long Beach, California, USA.

${ }^{4}$ Institut de Recherche pour le Développement, UR082/UMR Géosciences Azur, La Technopôle de Sophia Antipolis, Valbonne, France.

Copyright 2006 by the American Geophysical Union. 0148-0227/06/2005JC003249
}

by Pelletier et al. [2000b], Caminade et al. [2000], and Moore et al. [2000]. Observations and estimated runup heights are displayed in Table 1. A mean tide correction has been made to the observations reported by Pelletier et al. [2000b] in east and south Ambrym in order to make comparisons with the numerical predictions. In central Vanuatu, during the immediate period following the earthquake, the tide was near its lowest amplitude $(\sim 1.2 \mathrm{~m}$ below the highest tide amplitude for a $0 \mathrm{~m}$ lowest amplitude), see the Port Vila, Efate Island, tide gauge monitored by the National Tidal Facility, Flinders, Australia). Thus we added $0.6 \mathrm{~m}$ to their observations.

[3] In the south Pentecost Island the tsunami reached a maximum of $6.6 \mathrm{~m}$ above sea level at the southern tip of Martelli Bay, at the southern tip of Pentecost: that was the most damaged area: the village was destroyed (except the church) (Figure 2, bottom). The tsunami could have been more damaging because it occurred during the night. Fortunately, a wedding made the residents awake and the receding water warned them to run off the shore line. One eyewitness reported a water withdrawal succeeded by three waves. The first wave was reported to be smaller than the others and arrived within about $10 \mathrm{~min}$ of the earthquake. The first large wave (the second wave) was estimated to arrive approximately $15 \mathrm{~min}$ after the earthquake. Two successive sand deposit layers corroborated the two wave pulses described by the witness. The buildings, mostly wooden, were destroyed 

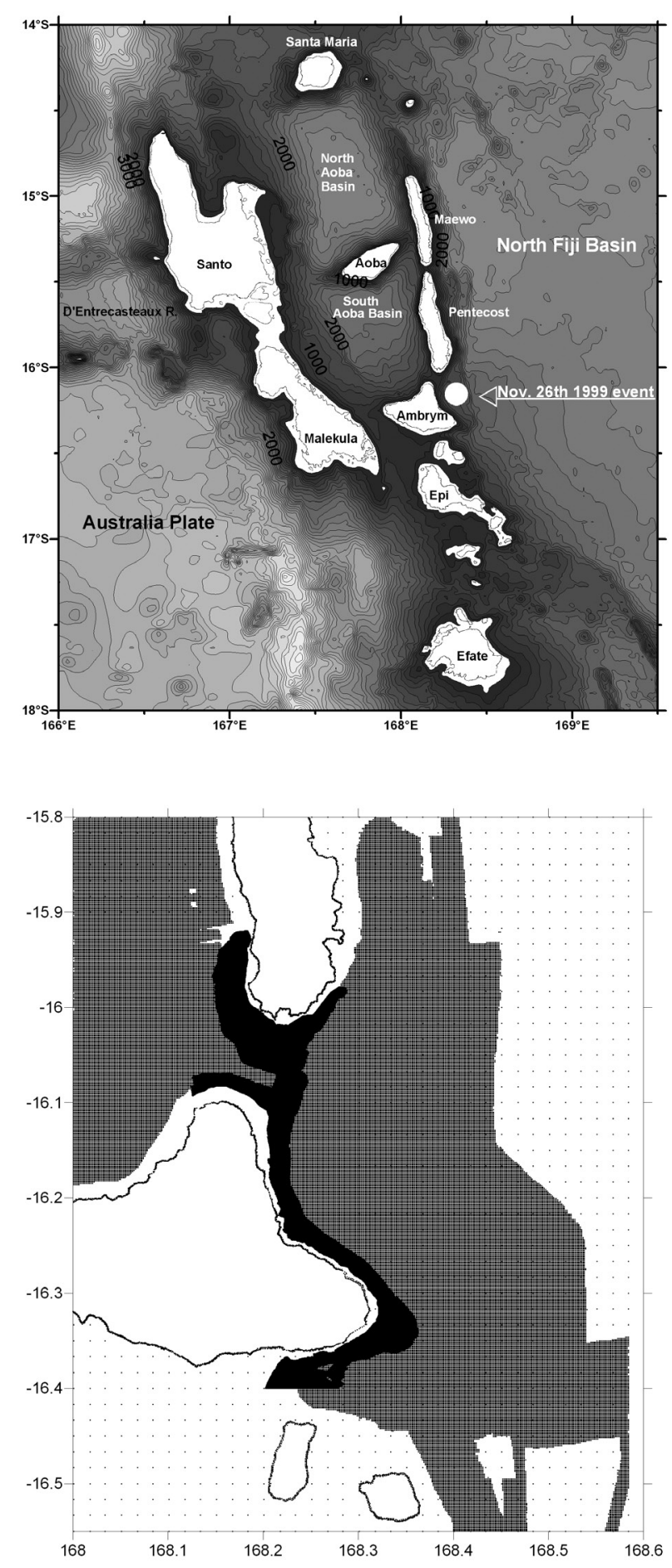

Figure 1. (top) Bathymetry of central Vanuatu (1 min grid, $200 \mathrm{~m}$ isointervals) along with the position of the 26 November 1999 earthquake. (bottom) Bathymetric sampling in the vicinity of Ambrym and Pentecost Islands. Each data point is pointed: the darker an area is, the better the sampling is. See the sampling details in the text.

except the church which culminates at $4.5 \mathrm{~m}$ high above the ground. The roof of the church was not subject to inundation indicating that the wave did not exceed the height of the church.
[4] As far as Ambrym Island is concerned, Pelletier et al. [2000b] report, along the easternmost part of Ambrym, a $2 \mathrm{~m}$ runup height for the south coast, a 3-4 m runup height for the north coast, and a 7-8 $\mathrm{m}$ runup height at the extreme east near Pamal. Landward limits of plant killed by salt water and some sand deposits give a runup of $2 \mathrm{~m}$ along the beach southeast of Taveak village. Near Renow at the eastern tip of Ambrym, blocks of lavas $(60-80 \mathrm{~cm})$ encrusted by dead read algae (now white due to desiccation) are isolated in black lavas blocks along the coast (Figure 2, top), indicating that these blocks, that were below sea level before the tsunami, have been transported upward (about $2 \mathrm{~m}$ ). People reported the presence of fishes in the upper part of the shore. Runup height is estimated here to be 3 $4 \mathrm{~m}$. A very high runup has been measured at the mouth of a small river just south of Pamal village. The plants killed by salt water indicate a runup of 7-8 $\mathrm{m}$ (Figure 2, middle). The wave penetrated largely into the river and huge blocks of several tons were moved on the shore. At this place natives collected fishes in the trees and grass far inside the river on 27 November in the morning. At Endu Pahakol on the north coast of the eastern part of Ambrym, an eyewitness reported that the tsunami arrived shortly after he was shaken by the quake. Farther north there is no observation for the eastern flank of the Ambrym Island because of its extreme slope. Runup heights of $2-3 \mathrm{~m}$ have been reported at the northern tip and along the northwestern coast of Ambrym [Caminade et al., 2000; Moore et al., 2000].

[5] Consistently, it has been reported that highest wave amplitudes were observed within the direction of radiation of the tsunami if that one was initiated by the east Ambrym earthquake: east Ambrym and southeast Pentecost area.

\section{Tectonics Summary of the Central Vanuatu}

[6] Across central Vanuatu between $14^{\circ} \mathrm{S}$ and $17^{\circ} \mathrm{S}$, the New Hebrides subduction zone is composed of the fore-arc belt (Espiritu Santo and Malekula Islands) which overthrusts westward the subducting Australian plate, the

Table 1. Maximum Tsunami Elevations Above Mean Sea Level ${ }^{\mathrm{a}}$

\begin{tabular}{lcc}
\hline \multicolumn{1}{c}{ Location } & Observed, $\mathrm{m}$ & Predicted, m \\
\hline Martelli Bay, south Pentecost & $6-7$ & $7-8(15 \%)$ \\
Barrier Bay, southeast Pentecost & $4.3-4.7$ & $5-5.5(17 \%)$ \\
South Mbarmel Anch., east Pentecost & $<1$ & $1.3(>30 \%)$ \\
North Guhunon Point & $5.2-5.4$ & $4.8-5.5(-3 \%)$ \\
South Ateu Point, southwest Pentecost & 2.9 & $2.3(-21 \%)$ \\
North Ateu Point, southwest Pentecost & 2 & $1.9(-5 \%)$ \\
Pamal, east Ambrym & $7.6-8.6$ & $8.5(5 \%)$ \\
Renow, east Ambrym & $3.6-4.6$ & $4.5(10 \%)$ \\
Taveak, south Ambrym & 2.6 & $1.5(-42 \%)$ \\
Point X, northeast Ambrym & 3.6 & $5.6(56 \%)$ \\
Nopul Anch., northwest Ambrym & $1.7-2.1$ & $1.9-2.4(13 \%)$ \\
South Meltow Point, west Ambrym & 2.2 & $1.9(-14 \%)$ \\
\hline
\end{tabular}

${ }^{\mathrm{a}}$ Computed maximum of sea surface elevation for the earthquakegenerated tsunami and estimated runups derived from observations [Caminade et al., 2000; Pelletier et al., 2000b]. A $+0.6 \mathrm{~m}$ mean tide correction has been made in the observations reported by Pelletier et al. [2000b] in south and east Ambrym (see the text). The sites are located in Figure 5. Point $\mathrm{X}$ is so named because it is not named by Caminade et al. [2000] nor identified in an available map of Ambrym. Since the exact positions of the observations are not provided by Pelletier et al. [2000b], the simulated wave heights are mentioned at the grid points neighboring the area of observation. The values inside the parentheses represent the relative gap between the computations and the observed values. 

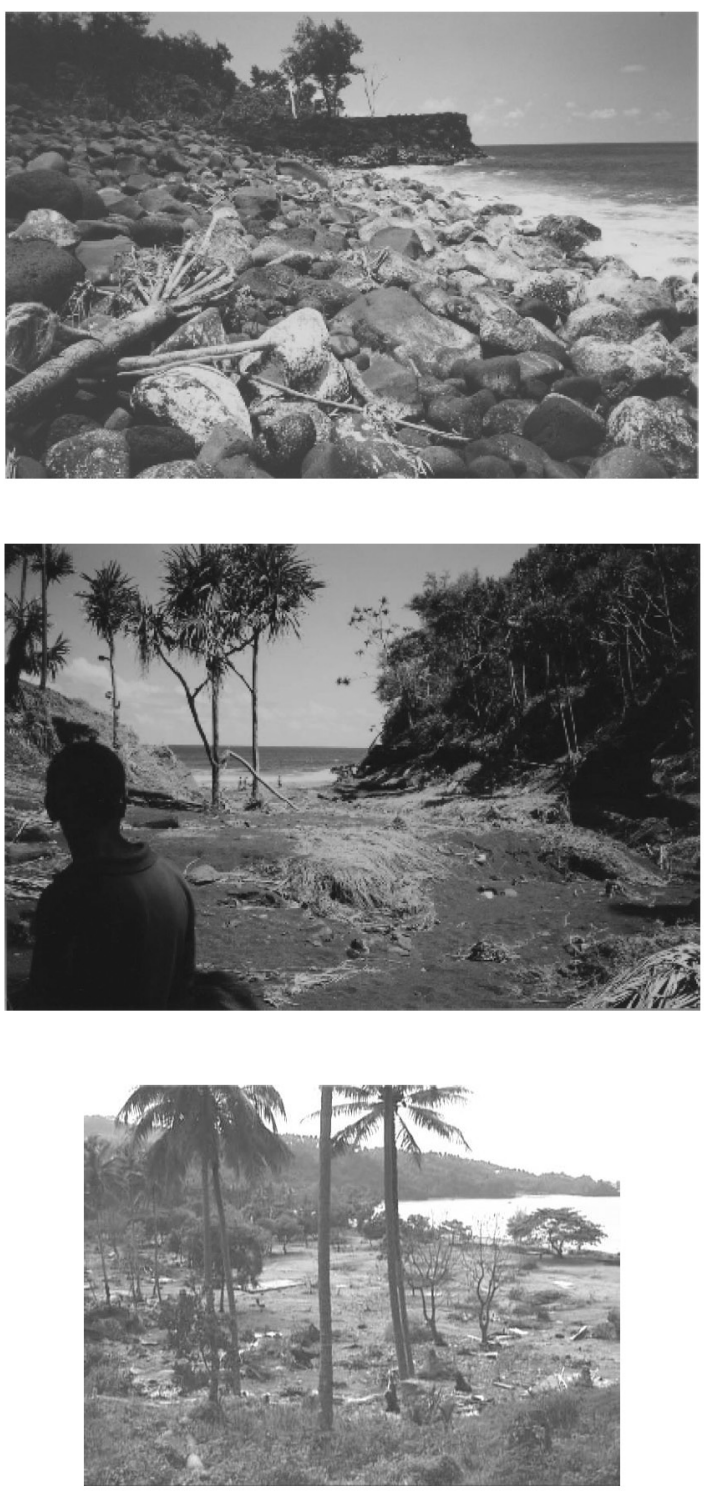

Figure 2. Posttsunami survey pictures. (top) Picture of the coast near Renow, eastern tip of Ambrym (photo by B. Pelletier, 13 December 1999). Blocks of lava $(60-80 \mathrm{~cm})$ encrusted by dead red algae (now white due to desiccation) are isolated in black lava blocks, indicating that these blocks have been transported from the sea (about $2 \mathrm{~m}$ in vertical). Runups here are estimated with other marks along the upper shore at 3.6-4.6 m. (middle) Picture at the mouth of a small river just south of Pamal village (photo by B. Pelletier, 13 December 1999). The plants killed by salt water indicate a runup of 7.6-8.6 $\mathrm{m}$ above the mean tide sea level. (bottom) Picture of Martelli Bay, south Pentecost, showing the destruction of the village by the tsunami (photo by J.-M. Bore, December 1999, from Pelletier et al. [2000b]).

intra-arc area which is mainly composed of the deep Aoba Basin and three active volcanoes (Santa Maria, Aoba and Ambrym Islands), and finally the back-arc belt (Maewo and Pentecost Islands) which back thrusts eastward onto the North Fiji Basin oceanic crust (Figure 1). This peculiar morphology of the central part of the Vanuatu arc (termed also the New Hebrides arc) is considered to be a direct consequence of the subduction/collision of the D'Entrecasteaux Ridge on the Australian plate [Collot et al., 1985; Taylor et al., 1987; Louat and Pelletier, 1989; Pelletier et al., 1994, 1998]. Both the western and eastern belts have been uplifted and are still subjected to present days positive vertical motion [Taylor et al., 1987; Lagabrielle et al., 2003].

[7] The 26 November 1999 earthquake was located in the southern part of the back-arc belt east of Ambrym Island [Regnier et al., 2003]. It was thought that such event should normally occur in the fore-arc area along the main plate boundary to accommodate the convergence motion. In reality, the earthquake occurred on the north-south trending back arc faults [Collot et al., 1985; Pelletier et al., 1994].

[8] Although it has been recognized that part of the regional convergence motion occurs along the back-arc belt [Louat and Pelletier, 1989], the fact that the convergence rates along the western and eastern belts are of same order have been recently established using GPS measurements [Taylor et al., 1995; Pelletier et al., 1998; Calmant et al., 2003]. Finally last GPS results indicates that the motion is even higher along the eastern belt. Indeed, Calmant et al. [2003] estimated a $5-6 \mathrm{~cm} / \mathrm{yr}$ of convergence rate along the eastern belt in the $\mathrm{N} 87^{\circ}$ direction and a $3-4 \mathrm{~cm} / \mathrm{yr}$ of convergence rate at the western plate boundary in the $\mathrm{N} 70^{\circ}$ direction.

[9] National Earthquake Information Center (NEIC) locations of significant earthquakes during the instrumental period indicate a succession of events along the back-arc thrust belt that are not distributed uniformly [Louat and Pelletier, 1989; Regnier et al., 2003]. The earthquake distribution is composed of active clusters (north of Maewo, northwest of Pentecost, Ambrym) that are separated by gaps. This is likely due to the nonuniformity of the stress field along the belt as a mechanical response to its curvature [Regnier et $a l ., 2003]$. The seismotectonics of the belt can be described as locked segments with a permanent seismicity between them [Regnier et al., 2003]. The Ambrym 26 November 1999 earthquake is located within the Ambrym segment. No earthquake of magnitude larger than $M_{w} 7$ has been reported along the back-arc belt during the last century except the Ambrym event. Considering the fault of a $M_{w} 7.5$ earthquake has about the same length than the average segment length along the back-arc eastern belt, similar large earthquakes might occur in the other segments [Regnier et al., 2003].

\section{Three Possible Tsunamigenic Structures}

[10] During the already planned Alaufi research cruise (detailed later), aboard the R/V l'Atalante, in March 2000, an opportunity was offered to process a bathymetry survey in order to analyze the geomorphology of the area where the 29 November Ambrym earthquake ruptured [Pelletier et al., 2000a]. These data combined with previously recorded multibeam data and other conventional echo sounder bathymetric data farther north along Maewo and Pentecost allow to well define the morphology of the east slope of the back-arc eastern belt.

[11] Figure 1 indicates a steep slope oriented $\mathrm{N} 170^{\circ}$ and extending to depths of $3000 \mathrm{~m}$ east of Maewo and Pentecost 
Islands. Farther south the slope transforms into two branches near the southeastern tip of Pentecost (near $16^{\circ} \mathrm{S}$ ). The shallower slope scarp (west, down to $1200 \mathrm{~m}$ ) follows the shorelines of the southeastern most part of Pentecost and the east side of Ambrym. The deeper slope (eastern branch), east of Ambrym, consists of a remarkably linear, $40 \mathrm{~km}$ long and $\mathrm{N} 165^{\circ}$ trending, 400- to 950-m-high scarp, the foot of it coinciding with the $2000 \mathrm{~m}$ isobath.

[12] Two peculiar morphological areas, have been found within the area of influence of the earthquake rupture, where the crust has been displaced. Although the structures have not yet been dated we propose to take them into account in the present tsunami study. The first submarine structure represents a land slide that is located northeast of the eastern point of Ambrym. The second structure is located in the Selwyn Strait between Ambrym and Pentecost Islands (Figure 3, top). The dynamics of the latter structure is subject to large uncertainty because available observations, mainly the bathymetry, are not sufficient to clearly identify the structure as a landslide or as an accumulation of lava deposits. In this study, we will, however, consider the structure as a landslide. The characteristics of the hypothetical landslides, taken from Lagabrielle et al. [2003], are reported here along with those of the fault rupture, the third (natural) tsunamigenic structure.

\subsection{Focal Mechanism of the 26 November 1999 Vanuatu Earthquake}

[13] The $M_{w} 7.526$ November 1999 earthquake has been first located by the NEIC at $168.21^{\circ} \mathrm{E}, 16^{\circ} 42^{\circ} \mathrm{S}, 33 \mathrm{~km}$ and by Harvard at $168.31^{\circ} \mathrm{E}, 16.08^{\circ} \mathrm{S}, 15 \mathrm{~km}$ (fixed). The NEIC location appears inconsistent with local seismological and crustal motion data (see Pelletier et al. [2000a], Regnier et al. [2003], and below). The centroid moment tensor solution (CMTS from Harvard) indicates a reverse fault with a strike of $174^{\circ}$, a dip of $30^{\circ}$ westward and a rake of $67^{\circ}$. Later, Regnier et al. [2003], on the basis of the local IRD network, located the event at $168.29^{\circ} \mathrm{E}, 16.19^{\circ} \mathrm{S}, 14 \mathrm{~km}$ and found that the strike and dip of the fault plane are $\mathrm{N} 170^{\circ}$ and $40^{\circ}$ respectively with a source duration estimate of $50 \mathrm{~s}$. They inferred from seismological considerations a rupture zone of $50 \times 25 \mathrm{~km}^{2}$. Considering this location and dip, the surface projection of the fault plane is very close to the linear $\mathrm{N} 165^{\circ}$ trending fault scarp lying at the depth of $2000 \mathrm{~m}$ east of Ambrym. Coseismic vertical motion (uplift as high as $1.2 \mathrm{~m}$ and even a little higher at $1.5 \mathrm{~m}$ ) and subsidence have been measured along the eastern shore of Ambrym and observed later around surrounding islands [Pelletier et al., 2000a; Lagabrielle et al., 2003]. The 30 GPS-recorded horizontal coseismic crustal displacements in the central Vanuatu sites indicate a mostly eastward trend; the motion at the closest site of the quake is $35 \mathrm{~cm}$ at the western tip of Ambrym Island [Pelletier et al., 2000b; Regnier et al., 2003]. The rupture characteristics were then obtained with Okada's [1985] dislocation model constrained with the GPS horizontal displacements estimates, the field survey measurements of vertical motions and the fault strike deduced from the bathymetry [Regnier et al., 2003]: Once the displacements are estimated, a dip angle is derived, a rake angle is proposed to take into account the deformation along strike (asymmetry) and the strike is deduced from the bathymetry with respect to the orientation of the fault. The best fit solution using a uniform rectangular fault is obtained with a $35 \times 20 \mathrm{~km}$ fault located at $168^{\circ} 31^{\circ} \mathrm{E}, 16.15^{\circ} \mathrm{S}, 7.5 \mathrm{~km}$ with the set of parameters displayed in Table 2 [Regnier et al., 2003]. The solution is plotted in Figure 4 which shows a good agreement between vertical motions and the solution. There is very good fit between the mapped fault scarp and the position of the surface fault trace inferred from seismology and crustal motion rupture geometry. According to this geometry and location, the rupture reached the sea floor surface at the scarp, and is the very good candidate as the source for the tsunami.

\subsection{East Ambrym Underwater Landslide (South Slide)}

[14] Lagabrielle et al. [2003] noticed one short valley within the $40 \mathrm{~km}$ linear east branch fault/scarp east of Ambrym (Figure 3, top). Upslope, the valley starts with a circular depression that can be assimilated to a landslide scar with slumped blocks inside. Downslope, the valley terminates with a $15 \mathrm{~km}$ wide sedimentary fan, probably composed of materials removed from the scar. Although the landslide has not yet been dated, it represents a good candidate as a source for the tsunami because it occurred strictly within the fault rupture area where the vertical displacements are maximum ( $>2 \mathrm{~m}$, see below). The characteristics of the possible landslide, mainly derived from Lagabrielle et al. [2003], are displayed in Table 3.

\subsection{South Pentecost Underwater Hypothetical Landslide (North Slide)}

[15] The third source candidate is another possible landslide that is located south of Pentecost Island in the Selwyn Strait (Figure 3, top). However, Lagabrielle et al. [2003], who suggested the landslide hypothesis, argued that the slide might have been built through possible recent lava deposits. This could explain the weakness of the slope $\left(10^{\circ}\right)$. However, at this stage, there is no choice but considering the scar as a possible tsunami source. The characteristics of this highly hypothetical landslide are displayed in Table 3.

\section{Numerical Simulation Settings of the 26 November 1999 Tsunami}

[16] We present in this section the numerical tools used to simulate the tsunami event. The sources are computed and the initial surface elevation are derived with TOPICS package. The propagation of the tsunami is simulated with FUNWAVE code with a special effort invested on the construction of the computational grids in order to optimize the numerical simulations.

\subsection{Methodology}

[17] Version 1.2 of the Tsunami Open and Progressive Initial Conditions System (TOPICS) provides the earthquake and slide tsunami sources in our work. For vertical coseismic displacement, TOPICS is based on the half-plane solution of an elastic dislocation problem [Okada, 1985]. A planar fault of length $L$ and width $W$ is discretized into many small trapezoids and the point source solution of Okada [1985] is used to sum the contributions made by each trapezoid to vertical coseismic displacement, based on the actual depth of the trapezoid. The shear modulus $\mu$ can be specified based on the depth of the earthquake centroid as 

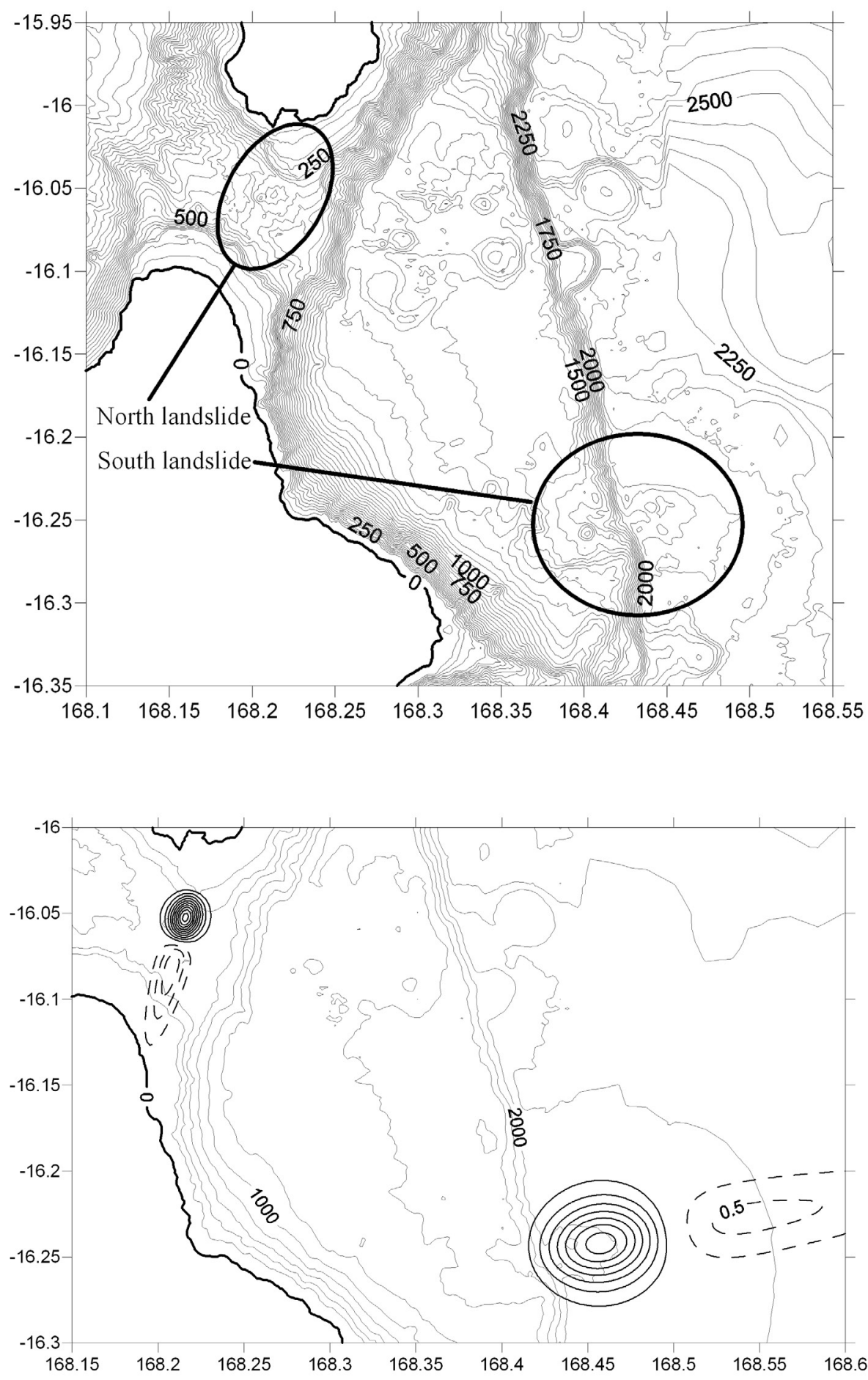

Figure 3. (top) Bathymetry (150 m grid, $50 \mathrm{~m}$ isocontours) of the east Ambrym-south Pentecost area along with locations of the north and south landslides. (bottom) Simulated initial vertical movement of the sea surface $(0.25 \mathrm{~m}$ isointervals $)$ along with the bathymetry $(200 \mathrm{~m}$ isocontours $)$. The landslide parameters are displayed in Table 3. Positives values represent sea surface depression, and negative values are set for sea surface elevation.

well as other seismic and geological descriptors. TOPICS outputs a characteristic wavelength $\lambda_{o}$ that is the smaller of the fault dimensions $L$ or $W$, and a characteristic tsunami amplitude $\eta_{o}$ that is the minimum depression found from the coseismic displacement. The seismic moment $M_{o}$ is proportional to but slightly less than $\mu L W \Delta$ because a Gaussian slip distribution is assumed about the centroid, where $\Delta$ is the maximum slip. TOPICS allows for the superposition of 
Table 2. The 1999 Vanuatu Fault Tsunami Source Parameters ${ }^{\mathrm{a}}$

\begin{tabular}{|c|c|}
\hline Quantities & Fault \\
\hline \multicolumn{2}{|c|}{ Inputs } \\
\hline$x_{o}$ (longitude), ${ }^{\circ} \mathrm{E}$ & 168.31 \\
\hline$y_{o}$ (latitude), deg & -16.15 \\
\hline$d, \mathrm{~km}$ & 7.5 \\
\hline$\varphi, \operatorname{deg}$ & 170 \\
\hline$\lambda, \operatorname{deg}$ & 64 \\
\hline$\delta, \operatorname{deg}$ & 140 \\
\hline$\Delta, \mathrm{m}$ & 6.5 \\
\hline$L, \mathrm{~km}$ & 35 \\
\hline$W, \mathrm{~km}$ & 20 \\
\hline$\mu, \mathrm{Pa}$ & $3.5 \times 10^{10}$ \\
\hline \multicolumn{2}{|c|}{ Outputs } \\
\hline$M_{o}, \mathrm{~J}$ & $1.35 \times 10^{20}$ \\
\hline$\lambda_{o}, \mathrm{~km}$ & 19.352 \\
\hline$\eta_{o}, \mathrm{~m}$ & 2.783 \\
\hline \multicolumn{2}{|c|}{$\begin{array}{l}\text { aThe inputs for TOPICS are, in descending order, the longitude of the } \\
\text { earthquake centroid } x_{o} \text {, the latitude of the earthquake centroid } y_{o} \text {, the } \\
\text { centroid depth } d \text {, the fault strike counterclockwise from north } \varphi \text {, the fault } \\
\text { rake clockwise from strike } \lambda \text {, the fault dip } \delta \text { (fault oriented west-east) and } \\
\text { dip counted clockwise, the maximum slip } \Delta \text {, the fault length along rupture } \\
L \text {, the fault width across rupture } W \text {, and the shear modulous } \mu \text {. The outputs } \\
\text { from TOPICS are the seismic moment } M_{o} \text {, the characteristic wavelength } \lambda_{o} \text {, } \\
\text { and the characteristic tsunami amplitude } \eta_{o} \text {. Note that in the simulation it is } \\
\text { imposed that the amount of slip is maximum at the fault centroid }(6.5 \mathrm{~m} \text { ) }\end{array}$} \\
\hline
\end{tabular}

multiple fault planes, which can be assembled into complex fault structures or slip distributions.

[18] For underwater slides, the initial free surface elevation and water velocities in TOPICS were derived from multivariate, semiempirical curve fits as a function of nondimensional parameters characterizing the landslide (e.g., density, geometry, etc.) and the local bathymetry (e.g., slope, depth, etc.). An initial water particles velocity is prescribed at depth $0.53 \times$ local depth. It is derived from the linear theory of progressive waves on water of arbitrary depth without any reference to the nature of the wave (short or long waves). The simple representation is better than an everywhere zero velocity. Relevant nondimensional parameters were selected based on numerical experiments constrained by experiments that were carried out first with the two-dimensional (2-D) model of Grilli and Watts [1999]. The curve fits were then modified based on results from a more recent 3-D model [Grilli et al., 2002]. The curve fitting approach that led to TOPICS was initially proposed by Grilli and Watts [1999]. The duration of landslide acceleration $t_{o}$ in the numerical simulations is also the duration of tsunami generation [Watts, 1998; Watts and Grilli, 2003]. Consequently, TOPICS provides a slide initial condition at time $t=t_{o}$, as if results from the models of Grilli and Watts [1999] or Grilli et al. [2002] were being transferred directly to the tsunami propagation model at that instant of time.

[19] We simulate tsunami propagation and inundation with FUNWAVE, a Boussinesq water wave model developed at the University of Delaware [Wei and Kirby, 1995; Wei et al., 1995; Chen et al., 2000; Kennedy et al., 2000]. FUNWAVE is a fully nonlinear Boussinesq model retaining information to $\mathrm{O}\left((k h)^{2}\right)$ in frequency dispersion and to all orders in nonlinearity $a / h$, where $k$ denotes an inverse wavelength scale, $a$ denotes a wave amplitude, and $h$ denotes a water depth. Wei et al. [1995] have demonstrated that the retention of nonlinear effects beyond the usual ordering in weakly nonlinear Boussinesq models is crucial to the correct modeling of shoaling solitary wave crests, and thus is important in the modeling of shoreline inundation. The presence of frequency dispersion in the model is important for the case of short-wave propagation into relatively deep water, and allows for the mechanism of wave crest splitting during wave propagation over shallow bathymetry. FUNWAVE includes dissipation from breaking waves, and model predictions of shoreline runup have been well tested in the case of short-wave shoaling and breaking. Runups have also been tested successfully tested for the cases with solitary waves on a shoal [Chen et al., 2000].

[20] We combine TOPICS and FUNWAVE into a single model referred to as Geowave, in which the tsunami sources predicted by TOPICS are transferred as initial conditions into FUNWAVE. Geowave can simulate multiple tsunami sources with different generation mechanisms, occurring at different times. The new software needed to manage multiple tsunami sources is one reason for the name Geowave. The benefits of a Boussinesq wave propagation model over traditional nonlinear shallow water wave models is that the horizontal velocity profile over depth is no longer constrained to have a constant value, and vertical accelerations (i.e., nonhydrostatic pressures) are no longer neglected. Dispersive effects are both necessary and manifested during propagation of deep water waves, during propagation of an undular bore, and during propagation of edge waves [ Liu et al., 1998]. Geowave has been validated based on case studies of a pyroclastic flow generated tsunami [Waythomas and Watts, 2003] and several underwater landslide generated tsunamis [Watts et al., 2003]. Geowave has also been applied to a debris flow generated tsunami [Walder and Watts, 2003].

\subsection{Bathymetric Sampling of Central Vanuatu and the Tsunami Computational Grid}

[21] Bathymetry comes from three data sets. The first data set is composed of all the available data in the central Vanuatu area $\left(165.5^{\circ} \mathrm{E}-170^{\circ} \mathrm{E} ; 18^{\circ} \mathrm{S}-13^{\circ} \mathrm{S}\right)$ collected along track lines either from conventional echo sounders or from multibeam systems (vertical beam only). This set includes in particular data from the Royal Australian Navy (RAN) acquired during numerous surveys of the M/V Cape Pillar in the Vanuatu Islands waters from 1984 to 1989. The data of the RAN surveys were available through the South Pacific Applied Geoscience Commission (SOPAC) and Vanuatu on paper copies, and have been fully digitalized at IRD-Nouméa. Maps from these data are in the works of Pelletier [1999] and Calmant et al. [2003]. The data set has been gridded at $1 \mathrm{~min}$ intervals (Figure 1).

[22] The second data set is composed of multibeam bathymetric data acquired in the area of Ambrym and Pentecost $\left(168^{\circ} \mathrm{E}-168.58^{\circ} \mathrm{E} ; 16.58^{\circ} \mathrm{S}-15.75^{\circ} \mathrm{S}\right)$ with the Simrad EM12 Dual system of the French R/V l'Atalante (Figure 1, bottom). Data in the Aoba Basin, north of Ambrym and west of Pentecost, was acquired in July 1993 during the SOPACMAPS leg 1 cruise of the SOPACMAP project [Auzende et al., 1994]. The data located east of Ambrym and Pentecost and in the Selwyn Strait between Pentecost and Ambrym Islands have been collected during the early days of the ALAUFI cruise in march 2000 [Pelletier et al., 2000a], a few months after the $M_{w}$ 7.5, 26 November Ambrym earthquake and tsunami. In fact the opportunity of the ALAUFI cruise was taken to 


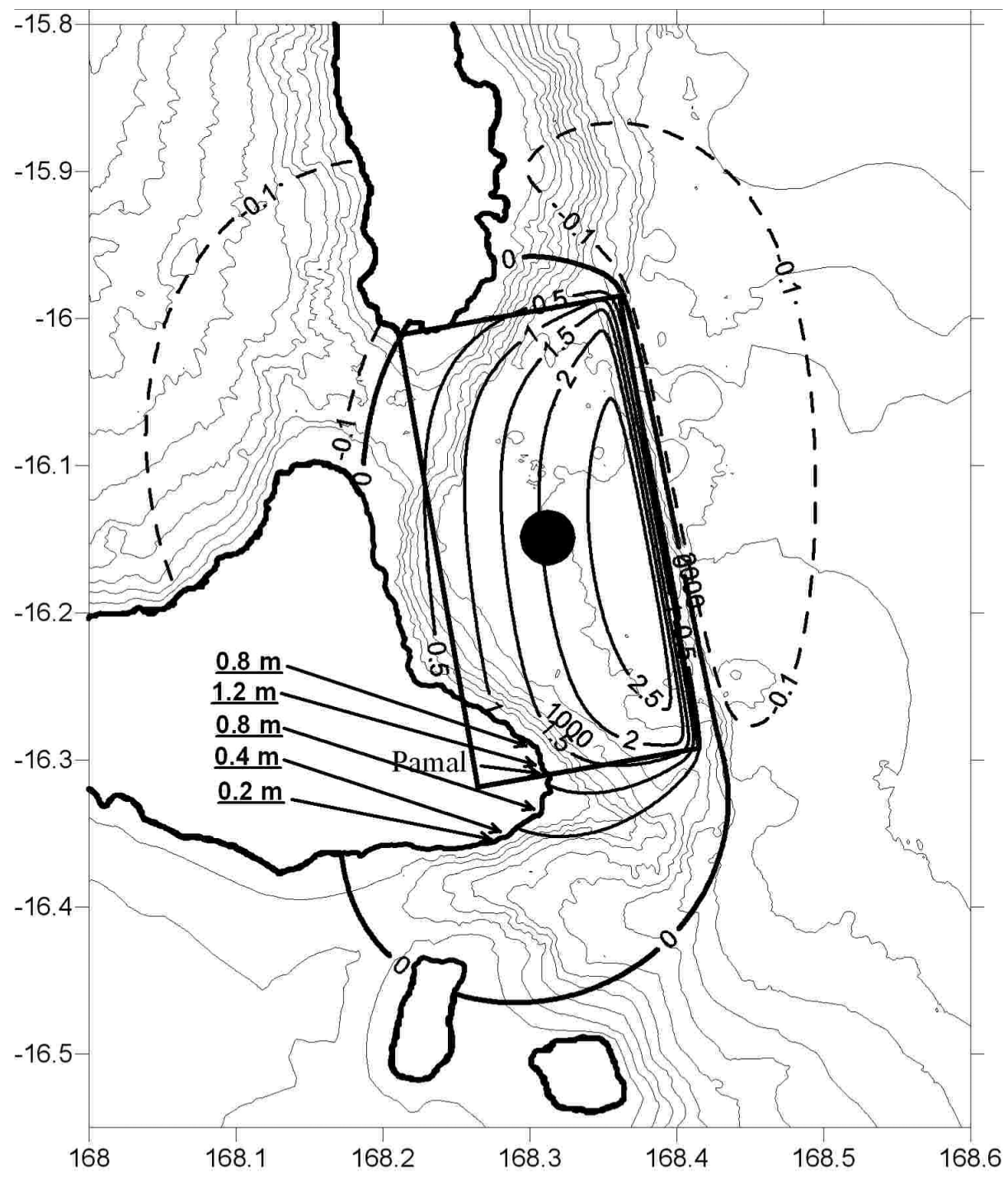

Figure 4. Simulated vertical displacements in meters with Okada [1985] dislocation model in the vicinity of the earthquake epicenter vertical along with the bathymetry [Regnier et al., 2003]. The rupture parameters are displayed in Table 2. Positives values represent uplift (positive initial sea surface elevation), and negative values are set for subsidence (initial sea surface depression). The vertical motions are estimated by Pelletier et al. [2000b], although field surveys are reported (underlined).

conduct on the transit way a 24 hour bathymetric survey around the ruptured area in order to characterize the possible morphological expressions of the fault and slide associated to the event. Four ship tracks made parallel to the east coasts of Ambrym and Pentecost and a return passage in the Selwyn Strait allow to map with full coverage the seafloor ranging in depth from 300 to $3000 \mathrm{~m}$ between $16.45^{\circ} \mathrm{S}$ to $15.83^{\circ} \mathrm{S}$ [Lagabrielle et al., 2003]. The grid size for this data set is about $150 \mathrm{~m}$.

[23] The third data set, sampled in Figure 1 (bottom), is composed of multibeam bathymetric data recently acquired in the area of Ambrym and Pentecost during TERRALIS Cruise in December 2003 with the Simrad EM1002 multibeam echo sounder of the IRD R/V Alis [Pelletier et al., 2004a, 2004b]. This swath mapping system is designed for high-resolution seabed mapping and acoustical imaging from the shoreline and down to a depth of $1000 \mathrm{~m}$. One of the objective of the cruise was to complete toward the shore the swath mapping previously made by the $\mathrm{R} / \mathrm{V}$ l'Atalante in order to improve the results of the tsunami modeling. The seafloor areas located around the southern tip of Pentecost, east of Ambrym and around the northern and eastern tips of Ambrym, and ranging in depth from 30-40 m to $500-600 \mathrm{~m}$ have been fully mapped. The grid size for this data set is $25 \mathrm{~m}$.

[24] The bathymetric grid used here for the tsunami propagation model results from these three data sets. The computational grid $\left(168^{\circ} \mathrm{E}-168.6^{\circ} \mathrm{E} ; 16.55^{\circ} \mathrm{S}-15.8^{\circ} \mathrm{S}\right.$; $150 \times 150 \mathrm{~m}$ intervals) is designed to study the local effects of the tsunami where most of the damages and significant runups have been registered (Figure 3).

\subsection{Derivations of the Three Distinct Tsunami Initial Conditions}

[25] The initial sea surface elevation is computed here for the three tsunami sources, using TOPICS software. The 
Table 3. Slide Tsunami Source Parameters ${ }^{\mathrm{a}}$

\begin{tabular}{lcc}
\hline \multicolumn{1}{c}{ Quantities } & South Slide & North Slide \\
\hline & Inputs & \\
$x_{o}$ (longitude), ${ }^{\circ} \mathrm{E}$ & 168.399 & 168.220 \\
$y_{o}$ (latitude), deg & -16.252 & -16.038 \\
$\varphi$ (orientation), deg & 280 & 165 \\
$\gamma$ & 1.854 & 1.854 \\
$b, \mathrm{~km}$ & 4 & 1 \\
$T, \mathrm{~m}$ & 60 & 50 \\
$w, \mathrm{~km}$ & 1 & 1 \\
$d, \mathrm{~m}$ & 1700 & 300 \\
$\theta, \mathrm{deg}$ & 26 & 10 \\
& & \\
$a_{o}, \mathrm{~m} / \mathrm{s}^{2}$ & Outputs & 0.5096 \\
$u_{\max }, \mathrm{m} / \mathrm{s}$ & 1.2865 & 47.79 \\
$s_{o}, \mathrm{~m}$ & 151.88 & 4483 \\
$t_{o}, \mathrm{~s}$ & 17930 & 94 \\
$\lambda_{o}, \mathrm{~km}$ & 118 & 5.09 \\
$\eta_{o}, \mathrm{~m}$ & 15.25 & -2.61 \\
\hline
\end{tabular}

${ }^{\mathrm{a}}$ The inputs for TOPICS are, in descending order, the longitude of the initial slide center $x_{o}$, the latitude of the initial slide center $y_{o}$, the counterclockwise orientation from north $\varphi$, the specific density $\gamma$, the initial landslide length $b$, the maximum initial landslide thickness $T$, the maximum landslide width $w$, the mean initial landslide depth $d$, and the mean initia incline angle $\theta$. The outputs from TOPICS are the slide initial acceleration $a_{o}$, the theoretical maximum (terminal) slide velocity $u_{\max }$, the characteristic distance of slide motion $s_{o}$, the characteristic time of slide motion $t_{o}$, the characteristic wavelength $\lambda_{o}$, and the characteristic tsunami amplitude $\eta_{o}$ from the depression wave at time $t=t_{o}$.

source parameters and the computed outputs are displayed in Tables 2 and 3.

[26] The earthquake source generated surface elevations that are displayed in Figure 4 and is derived from the best fit solution of Regnier et al. [2003]. Since the fault parameters have been constrained to the observed coseismic vertical displacements, the computed elevations fit well the ground uplifts/subsidences estimated by Pelletier et al. [2000b]. In particular the easternmost side of Ambrym experienced the most significant vertical elevations with a maximum of $1.2 \mathrm{~m}$ around Pamal, decreasing quickly to the west. The maximum of uplift is located offshore near the eastern branch fault $(\sim 2.8 \mathrm{~m})$. Most of Ambrym and Pentecost Islands experienced a weak subsidence (not measurable in situ). TOPICS outputs reveals a typical tsunami wavelength of $\sim 20 \mathrm{~km}$ which covers most of the ocean area around east Ambrym and south Pentecost. The derived local tsunami (the one radiating nearly westward) is thus expected to strike quickly the coasts and with nearly the total initial loaded energy. The distant tsunami, radiating eastward will not be considered in the present study since no island is expected to reflect it backward.

[27] The south and north landslides are hypothetical since they are not dated. Considering their morphology and location, we already stated that the south landslide is a better candidate for contributing in the tsunami generation [Lagabrielle et al., 2003]. However, because of the large uncertainty on their date of occurrence (south and north landslides) and/or its effectiveness (north landslide), we will refer to their possible contributions only if the tsunami generated by the rupture in the eastern Ambrym branch fault does not fit reasonably the tsunami data survey and timing displayed in Table 2 .

[28] The two landslides differ significantly in their induced volumes displaced and their mean depths and slopes.
The south landslide (deeper, steeper, and more voluminous) generates a larger tsunami wave period which (Table 3), we expect, is likely to have a larger timescale and a broader space influence although the south landslide initial induced elevation is more important because of the shallowness of the movement. The initial surface elevations derived from the two landslide sources are mapped in Figure 3 (middle).

\section{Numerical Results and Discussion}

[29] Table 1 indicates a relatively good agreement between computed maximum of elevation and observed runups. It is noticed that the runup measurements were subject to errors of up to several tens of centimeters. The main reasons for that good fit are the propagation model resolving of the westward radiative direction and the quality of the bathymetry data sets that allow to resolve most of the site effects. The numerical simulation of earthquake-induced tsunami gives the following results.

[30] In Ambrym, a very good agreement is found at the mouth of the river near Pamal. This is certainly due to focussing effects of the bay since the wave amplitude was only a third of the coastal value $300 \mathrm{~m}$ offshore (2 grid points eastward) and half of the value is found farther north near Renow for a same direction of radiation of the wave. May we stress here the benefits provided by the bathymetry data sets. Compared to the other very satisfactory comparisons, in south Ambrym, near Taveak, the simulated wave amplitude underestimates the observation, mainly because the bathymetry (thus the computational bathymetry grid) does not resolve the coral reef passage present offshore Taveak. It is fair to stress however that the simulated and observed values are of same order of amplitude. We may address the same comment for Point $\mathrm{X}$ and more generally for the north Ambrym coast: Caminade et al. [2000] provided several estimates of runup on that segment that we could not validate because the bathymetry does not resolve the extended shallow coral shelf (hundreds of meters). The Ambrym western flank is also resolved coherently indicating the good simulation of the refraction of the wave off the Selwyn Strait.

[31] Southeast Pentecost stands in the direction of the wave radiation and is thus subject to damaging inundation. As seen in Figure 5, the maximum wave height drops abruptly from south Mbarmel Anch. The area looks like a shadow area where the wave is likely to be diffracted. This is stressed by the very weak wave amplitude gradient from coast to offshore (Figure 5). Here again the simulation fits relatively well observations. Thirty percent may look important but the simulated wave amplitude drop from southeast Pentecost to the northern segment at this critical point is very similar to observations. Southwest Pentecost, south of Ateu Point, is subject to high waves due to a trapping of the wave train within the well-marked bay. Farther north the wave propagates along the shore limiting its amplification, then it amplifies again when the coast presents some incidence with the wave.

[32] Within the Ambrym Pentecost area, the only data taking into account the timing of the wave is one eyewitness report in Martelli Bay, south Pentecost. The timing is reported as follows: first was observed a water withdrawal, then a succession of three waves. The first wave arrived approximately $10 \mathrm{~min}$ of the earthquake event, then two 


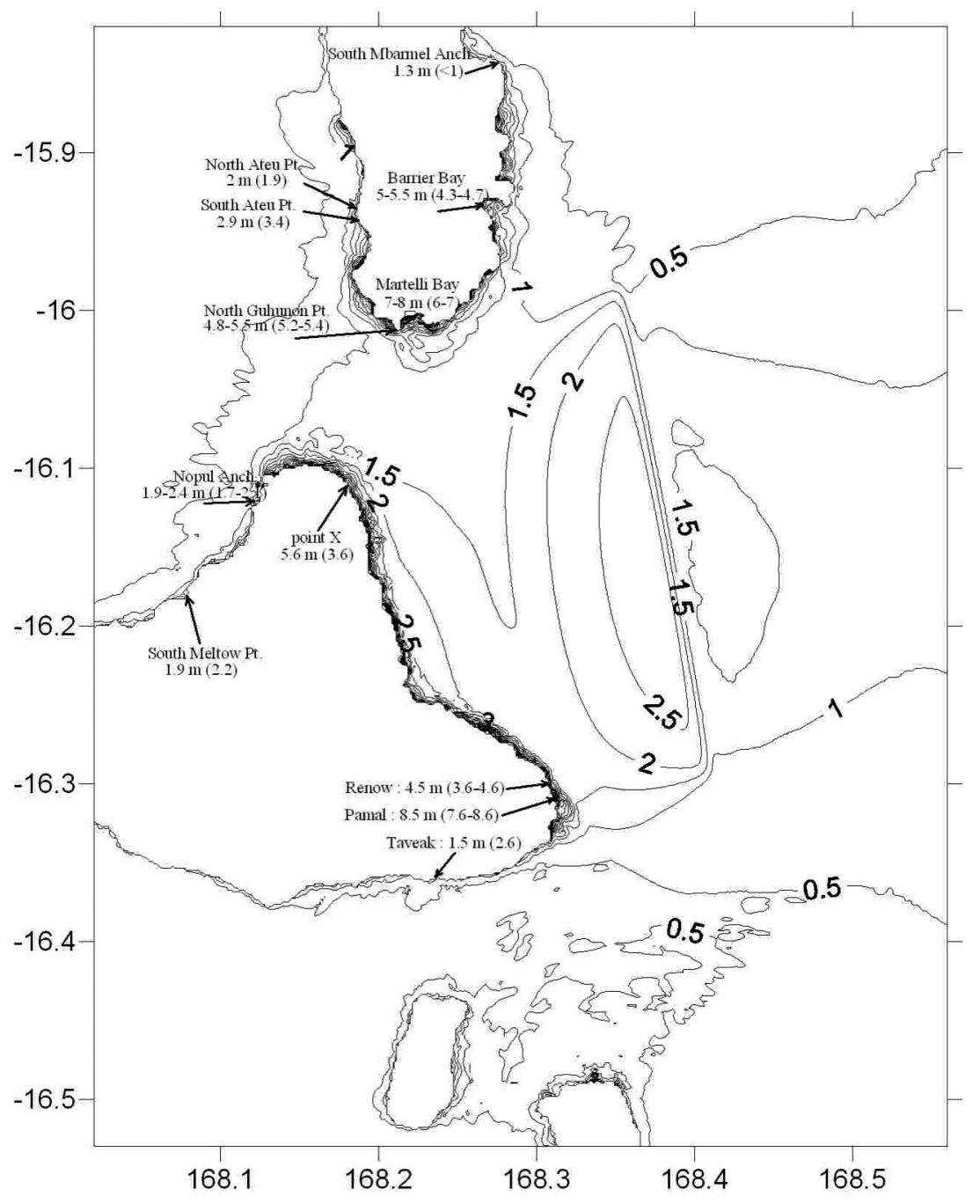

Figure 5. Computed maximum of sea surface elevation maps for the earthquake-generated tsunami (0.5 $\mathrm{m}$ isointervals). Estimated runups derived from observations [Caminade et al., 2000; Pelletier et al., 2000b] are reported in brackets. Observations are related to the mean tide elevation value (Table 1).

larger waves arrived 15 min apart. In our computations, we have placed a virtual tide gauge within the Martelli Bay close to the coast line.

[33] Before going further it is fair to say that the Martelli Bay bathymetry was not available. The high-density bathymetry processed during TERRALIS cruise did stop at the bay passage. We processed manually a smooth matching from the last bathymetry point (around $30 \mathrm{~m}$ depth valued) to the coastline for an average range of six to seven grid points. This simple empirical methodology is consistent with the very smooth slope of the bay. At this stage it is necessary to present some numerical sensitivity tests in order to comfort our confidence in the model used and in our results.

[34] Figure 6 shows the strong dependence between the grid spacing and the numerical results. The severe discrepancy between the $0.5^{\prime}$ grid and 300 and $150 \mathrm{~m}$ ones stresses the necessity to build an accurate and fine-resolution computational in relation with the intial wavelength. Note that for the $300 \mathrm{~m}$ grid spacing the simulated record is a little south of that of the $150 \mathrm{~m}$ one which explains the $30 \mathrm{~s}$ discrepancy in the arrival time. Besides, the amplitudes of the first waves are slightly different because the depth of the records are also slightly different ( $8 \mathrm{~m}$ and $6 \mathrm{~m}$ respectively), thus both waves are subject to a slightly different shoaling. The discrepancies amplify with time because of the wave propagation within the bay. Considering these artificial discrepancies, the test indicates that the wave signal has converged from the $300 \mathrm{~m}$ to the $150 \mathrm{~m}$ grid spacing.

[35] An other issue regards to the validation of our results concerns the physics that is taken into account in FUNWAVE. In Figure 7, we are testing the dispersion effects. We compare the same wave signal at Martelli Bay obtained with Geowave (dispersive) to the one computed with a linear dispersion relation (nondispersive). The arrival time is similar for the two simulations and the amplitude and phase are of same order for the first crests. This may be due to the fact that the wave propagated on open sea in its way from the source to that location without any bathymetric accident, and encountered a weak slope from the entrance of the bay 


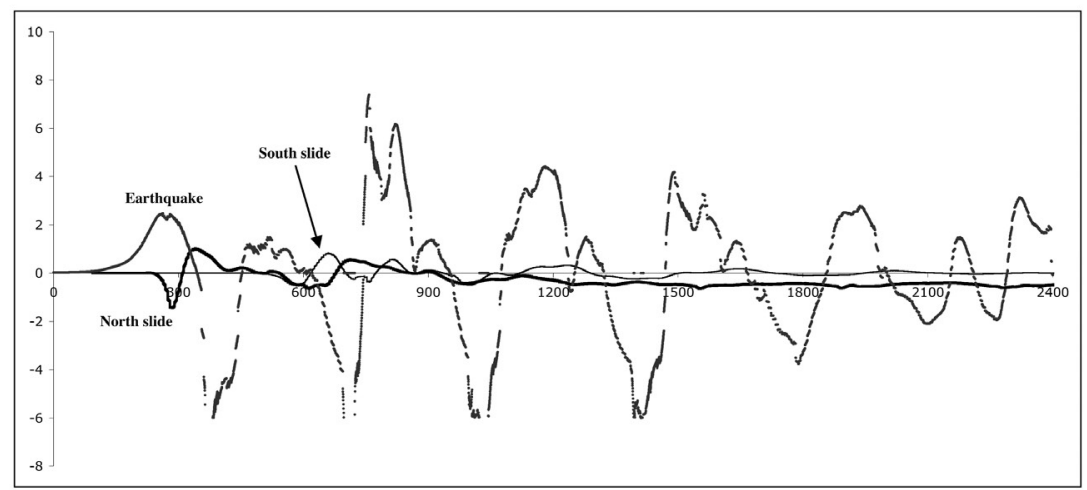

Figure 6. Simulated time sequences in Martelli Bay, south Pentecost, for three grid spatial resolutions: (1) $150 \mathrm{~m}$ spacing at $168.221^{\circ} \mathrm{E}, 16.005^{\circ} \mathrm{S}$, depth $=6 \mathrm{~m}$; (2) $300 \mathrm{~m}$ spacing at $168.221^{\circ} \mathrm{E}, 16.005^{\circ} \mathrm{S}$, depth $=8 \mathrm{~m}$; and (3) $1 / 2^{\prime}$ for $168.221^{\circ} \mathrm{E}, 16.006^{\circ} \mathrm{S}$, depth $=6 \mathrm{~m}$.

to the coast line. The discrepancies increase in the second half of the signal because, precisely, the wave was subject to the very shallow water depth of the bay through reflections for example. In this portion of time we need dispersion to reproduce the wave sequence (celerity and phase).

[36] Finally, to finish with the validation tests, we have recorded the wave signal along a trace oriented south-north from a depth $291 \mathrm{~m}$ to depth $6 \mathrm{~m}$ (Figure 8). For the first crest, due to the weak slope within the Martelli Bay (33 m at the entrance of the bay only), the shoaling between the two locations is not significant (from $1.90 \mathrm{~m}$ amplitude at $33 \mathrm{~m}$ depth to $2.5 \mathrm{~m}$ at $6 \mathrm{~m}$ depth). In contrast, the third crest amplitude at $6 \mathrm{~m}$ depth is twice that at $33 \mathrm{~m}$. Consequently, the large wave observed in Martelli Bay (the third) that was the most damaging seems to be attributed mostly to the geometry of the bay. It is, however, difficult to identify the process involved in this geometry effect because there is not here a tide gauge that would evidence a particular frequency of resonance of the bay that could be compared to the simulated signal. Nevertheless, from this result, we address two statements. First, our bathymetry was interpolated from the entrance of the bay to the coastline. This lack of data is not a real handicap because the slope is very weak. Second, our coastline is accurate and thus we are necessarily likely to reproduce correctly the effect of the geometry of the bay on the wave signal. Since this seems to be the main process involved for the most damaging wave we may argue that our computational grid is accurate.

[37] Back to the numerical results, in Figure 9 we present the simulated wave signals for the earthquake and land slides derived tsunamis. For the earthquake, a first wave peak $(\sim 2 \mathrm{~m})$ is simulated $5 \mathrm{~min}$ after of the earthquake event. Then a severe depression occurred (no more water at this $6 \mathrm{~m}$ mean level depth grid point) $6.5 \mathrm{~min}$ after the event. A moderate peak follows $(1.4 \mathrm{~m}) 9 \mathrm{~min}$ after the event. Then, one large wave ( $>6 \mathrm{~m})$ composed of two spots arrived $13.5 \mathrm{~min}$ after the event, which where followed by one large amplitude ( $>4 \mathrm{~m}$ ) peak 20 min after the event, and another large but shorter peak.

[38] Apparently there is an immediate contradiction between the eyewitness report and the simulation results: the witness reported a withdrawal before the first wave and the simulation reveals a relatively moderate peak first. It is fair to state, however, that the second simulated peak matches the eyewitness first peak timing and amplitude (relatively small amplitude and $\sim 10 \mathrm{mn}$ past the earthquake event). This uncertainty forced us to analyze the possible contribution of the two hypothesized landslide tsunami elements which were forced to be initiated at the same time as the earthquake event. Figure 8 shows for both landslides a

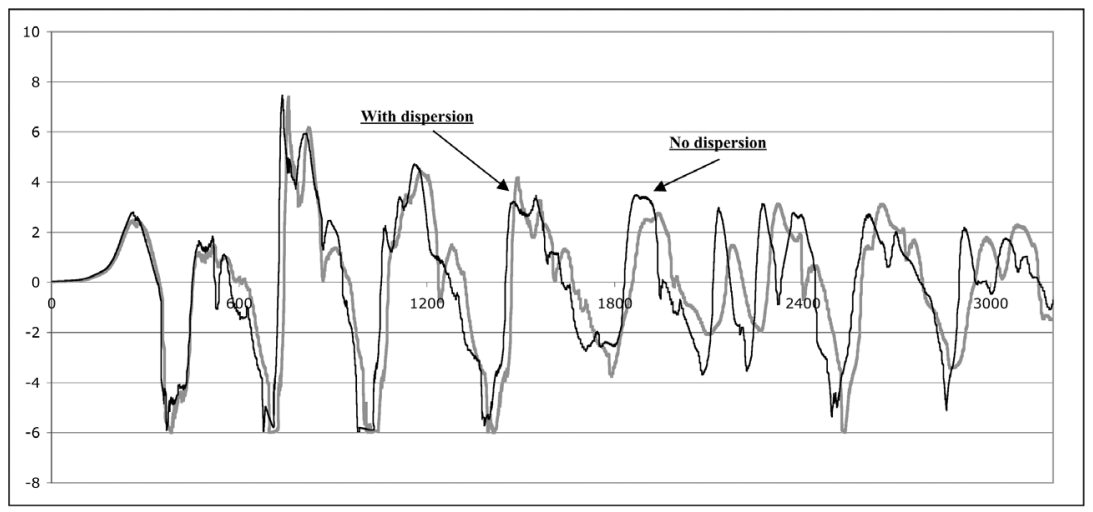

Figure 7. Simulated time sequences in Martelli Bay, south Pentecost $\left(168.221^{\circ} \mathrm{E}, 16.005^{\circ} \mathrm{S}\right.$, depth $=$ $6 \mathrm{~m})$ with and without dispersion. 


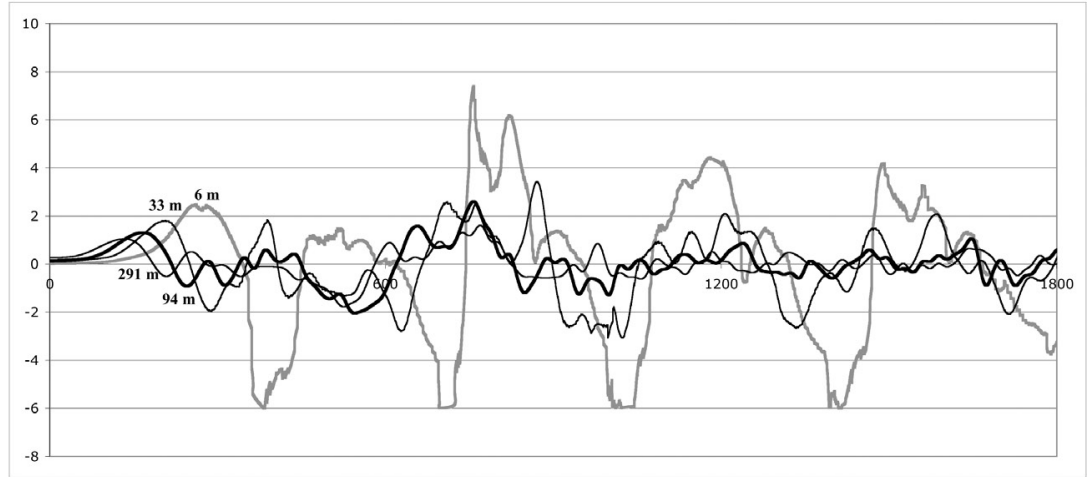

Figure 8. Simulated time sequences south of Martelli Bay coast line, south Pentecost, at points $168.221^{\circ} \mathrm{E}, 16.005^{\circ} \mathrm{S}$, depth $=6 \mathrm{~m} ; 168.221^{\circ} \mathrm{E}, 16.011^{\circ} \mathrm{S}$, depth $=33 \mathrm{~m} ; 168.221^{\circ} \mathrm{E}, 16.022^{\circ} \mathrm{S}$, depth $=$ $94 \mathrm{~m}$; and $168.221^{\circ} \mathrm{E}, 16.041^{\circ} \mathrm{S}$, depth $=291 \mathrm{~m}$.

receding wave (a trough) which is also of higher amplitude for the north landslide. However, the first trough (the north landslide) starts when/after the first earthquake simulated peak is reached. Thus the landslide hypothesis could not remove the uncertainty by lowering the earthquake peak and it would have been worse if the landslides occur later. Besides it would not have been a reasonable frame work to initiate the landslides before the earthquake event in order to fit better the observations.

[39] Since the maximum elevations are reasonably well predicted with the fault rupture tsunami only, we try in the following to analyze if there is an objective interpretation of the observations that could explain the predicted results. First the tsunami stroke Martelli Bay at night local time. At that location and time, the tide was at its lowest amplitude (see the Port Vila, Efate Island, tide gauge monitored by the National Tidal Facility, Flinders, Australia). The gauge indicates a maximum tide elevation of $1.5 \mathrm{~m}$ at $0900 \mathrm{UT}$ and a minimum $(0 \mathrm{~m})$ at around $1530 \mathrm{UT}$. At the arrival of the first peak at Martelli Bay (1325 UT) the tide is approximately $0.3 \mathrm{~m}$ high. If we speculate that the eyewitness would not have been surprised if the sea surface elevation was at its highest tide amplitude $(\sim 1.5 \mathrm{~m}$ from the lowest) while it is near its lowest one $(0.3 \mathrm{~m}$, and $1.2 \mathrm{~m}$ from the highest), there is still a $\sim 0.8 \mathrm{~m}(2 \mathrm{~m}$ simulated $1.2 \mathrm{~m}$ ) residuals. Pictures of Martelli Bay (Figure 2, bottom) show that such residuals could have been ignored by an eyewitness because the inhabited area stands much higher in topography than this residual elevation from the mean sea level. Thus one possible objective interpretation is that the eyewitness did not notice the first simulated wave. However he could not miss the unusual water withdrawal that is clearly predicted in our simulation. Then, the second simulated peak is more likely to retain attention of one eyewitness who may report this second wave as the first one. Then the subsequent timing fits relatively well the

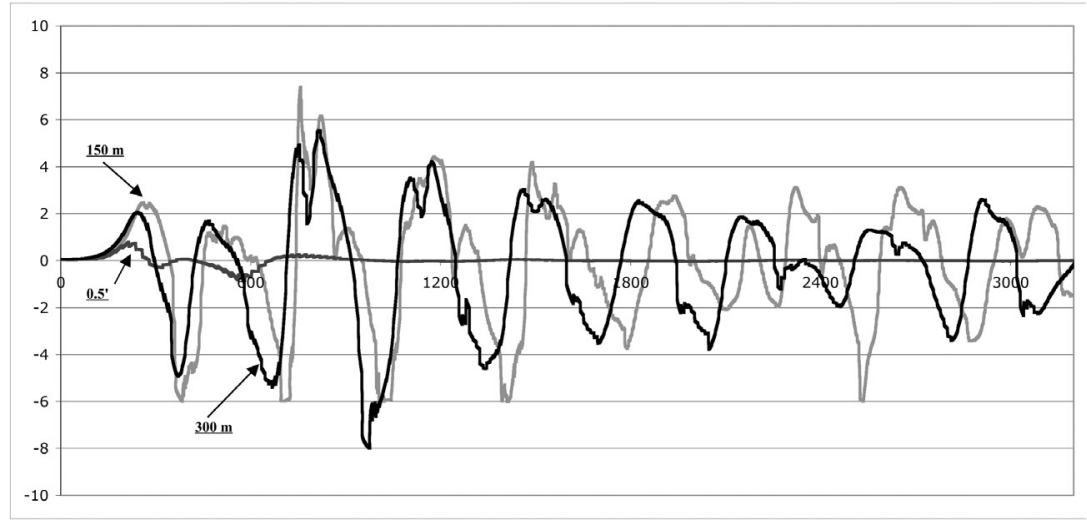

Figure 9. Simulated time sequence in a point of Martelli Bay, south Pentecost $\left(168.221^{\circ} \mathrm{E}, 16.005^{\circ} \mathrm{S}\right.$, depth $=6 \mathrm{~m}$ ). Time is displayed in seconds, and wave amplitudes are displayed in meters. Three sources are taken into account: the earthquake source and the north and south landslides. Note that an approximately $-30 \mathrm{~cm}$ set down is simulated for the north slide that lasts for the whole $40 \mathrm{~min}$ simulation. This slide is very close to the south Pentecost coast and is confined within the Ambrym-Pentecost channel. As far as there is a strong asymmetry (crest of lower amplitude than trough) of the initial wave (Figure 3, bottom), there might be a trapping of a signal trending to a depression within the relatively closed Martelli Bay. Boussinesq equations conserve the overall zero mean sea level in the whole domain, but locally, we still have a persistent depression even after a 2 hour simulation (not shown). We assume that the return to the equilibrium will be resolved at a much greater timescale locally. 

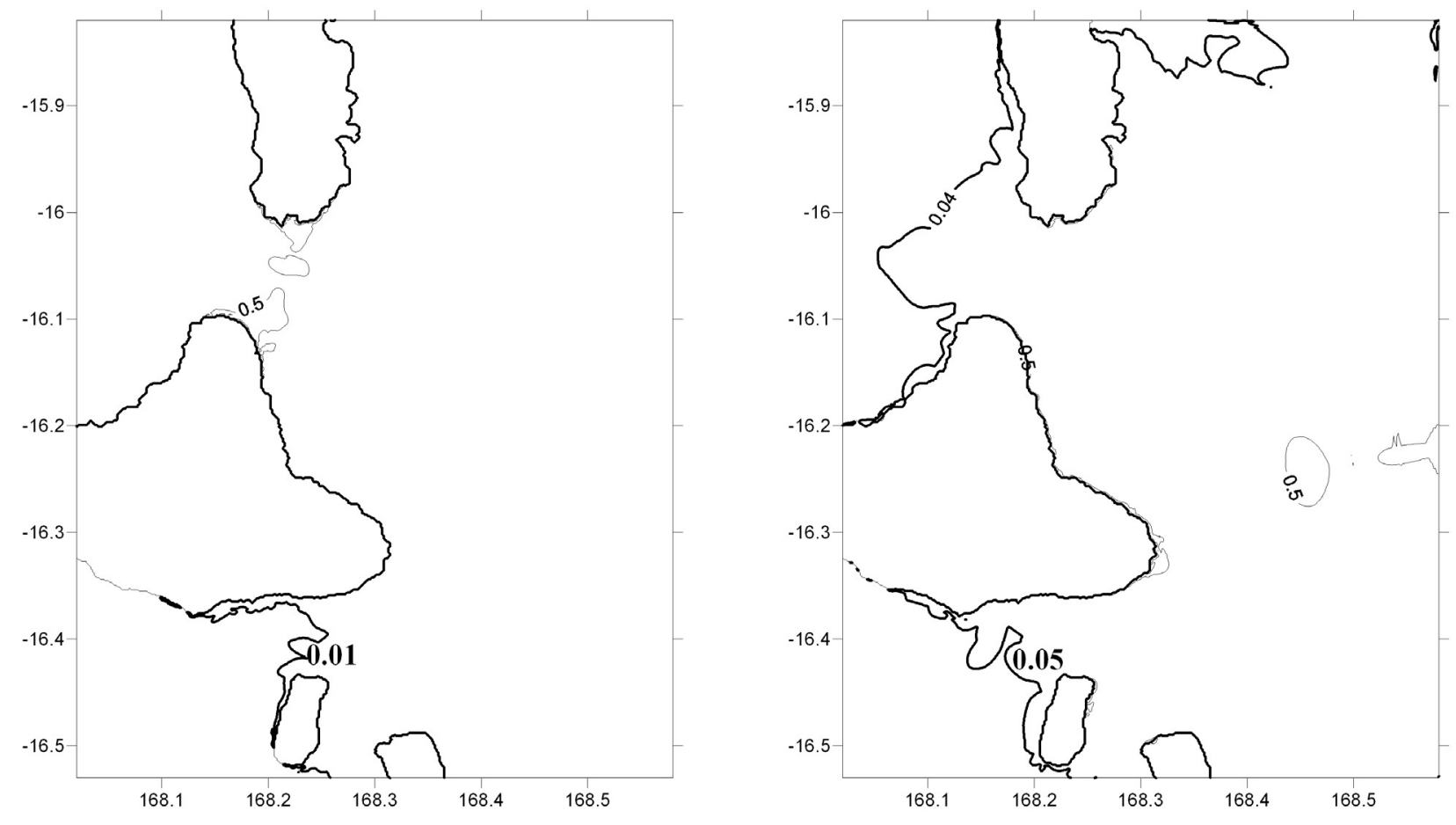

Figure 10. Computed maximum of sea surface elevation maps for the two landslides $(0.5 \mathrm{~m}$ isointervals). (left) North landslide, for which the $1 \mathrm{~cm}$ isoelevation is located. (right) South landslide, for which the $5 \mathrm{~cm}$ isoelevation is located.

eyewitness reports: two great waves follow the moderate wave $\sim 15 \mathrm{~min}$ apart the earthquake. The fifth relatively important predicted wave $(3-4 \mathrm{~m})$ was not noticed by the eyewitness, but maybe he was not asked to talk about the whole wave train or simply he did not report the wave since only the large prior ones were of importance for him. Besides, this wave is composed of two spots of short wave period which are more sporadic than the largest ones. The following successive peaks are due to the confinement of the wave within the Martelli Bay.

[40] Finally, the maximum of tsunami wave amplitudes that are derived from the two hypothetical landslides do not contribute significantly to the damaging amplitudes computed with the earthquake-derived tsunami (Figure 10). Their effect is of limited amplitude and area of influence. The proximity of the 5 and $1 \mathrm{~cm}$ elevation tsunami expanding limits to the landslide sources plotted in Figure 9 enhances the statement. Thus we may conjecture that the earthquake-derived tsunami alone explains most of the posttsunami survey observations without taking into account the hypothetical landslides. That statement does not exclude their occurrence but simply limits their effects.

[41] Acknowledgments. The authors would like to acknowledge with thanks the computational help of Stéphane Operto from Géosciences Azur and the referees who contributed to a substantial improvement of the firstdraft manuscript. This work was partly funded by the French Ministère de l'outre mer through a grant attributed to M. I and B. P for the period 20042006.

\section{References}

Auzende, J. M., J. Daniel, and B. Pelletier (1994), Mapping of the PacificAustralian plate boundary with SIMRAD EM12 (Sopacmaps cruise), paper presented at the Sixth Pacific Congress on Marine Science and Technology, PACON '94, James Cook Univ. of N. Queensl., Townsville, Australia, 4-8 July.

Calmant, S., B. Pelletier, M. Lebellegard, M. Bevis, F. W. Taylor, and D. A. Phillips (2003), New insights on the tectonics along New Hebrides subduction zone based on GPS results, J. Geophys. Res., 108(B6), 2319, doi:10.1029/2001JB000644.

Caminade, P., D. Charlie, U. Kanoglu, S.-I. Koshimura, H. Matsutomi, A. Moore, C. Ruscher, C. Synolakis, and T. Takahashi (2000), Vanuatu earthquake and tsunami cause much damage, few casualties, Eos Trans. $A G U, 81(52), 641,646-647$.

Chen, Q., J. T. Kirby, R. A. Dalrymple, A. B. Kennedy, and A. Chawla (2000), Boussinesq modeling of wave transformation, breaking, and runup. II: 2D, J. Waterw. Port Coastal Ocean Eng., 126, 48-56.

Collot, J.-Y., J. Daniel, and R. V. Burne (1985), Recent tectonics associated with the subduction/collision of the D'Entrecasteaux zone in the central New Hebrides, Tectonophysics, 112, 325-356.

Grilli, S. T., and P. Watts (1999), Modeling of waves generated by a moving submerged body: Applications to underwater landslides, Eng. Anal. Boundary Elements, 23, 645-656.

Grilli, S. T., S. Vogelmann, and P. Watts (2002), Development of a 3-D numerical wave tank for modeling tsunami generation by underwater landslides, Eng. Anal. Boundary Elements, 26, 301-313.

Kennedy, A. B., Q. Chen, J. T. Kirby, and R. A. Dalrymple (2000), Boussinesq modeling of wave transformation, breaking, and run-up. I: 1D, J. Waterw. Port Coastal Ocean Eng., 126, 39-47.

Lagabrielle, Y., B. Pelletier, G. Cabioch, M. Régnier, and S. Calmant (2003), Coseismic and long-term vertical displacement due to back arc shortening, central Vanuatu: Offshore and onshore data following the $M_{w}$ 7.5, 26 November 1999 Ambrym earthquake, J. Geophys. Res., 108(B11), 2519, doi:10.1029/2002JB002083.

Liu, P. L.-F., H. Yeh, P. Lin, K.-T. Chang, and Y.-S. Cho (1998), Generation and evolution of edge-wave packets, Phys. Fluids, 10, 1635-1657.

Louat, R., and B. Pelletier (1989), Seismotectonics and present day relative plate motions in the New Hebrides-North Fiji Basin region, Tectonophysics, 167, 41-55.

Moore, A. L., F. Imamura, H. Matsutomi, C. Synolakis, T. Takahashi, and S. Koshimura (2000), Report on the damage caused by the 26 November 1999 tsunami in Vanuatu, Misc. Rep. 387, SOPAC, Suva, Fiji.

Okada, S. (1985), Surface displacement due to shear and tensile faults in a half-space, Bull. Seismol. Soc. Am., 75, 1135-1154. 
Pelletier, B. (1999), Subduction de rides et ouvertures arrière-arc dans le Pacifique Sud-Ouest (arcs des Tonga-Kermadec et du Vanuatu, bassins de Lau et Nord-Fidjien), in Mémoire d'Habilitation à diriger des recherches, vol. 1, 102 pp., Univ. de Paris VI, France.

Pelletier, B., M. Meschede, T. Chabernaud, R. Roperch, and X. Zhao (1994), Tectonics of the Central New Hebrides arc, North Aoba basin, Proc. Ocean Drill. Program Sci. Results, 134, 431-444.

Pelletier, B., S. Calmant, and R. Pillet (1998), Current tectonics of the Tonga-New Hebrides region, Earth Planet. Sci. Lett., 164, 263-276.

Pelletier, B., Y. Lagabrielle, M. Benoit, M. Boda, G. Cabioch, S. Calmant, E. Garel, C. Guivel, and J. Perrier (2000a), Campagne Alaufi N.0. L'Atalante, 29 février au 17 mars 2000, Mission Rep. 42, 95 pp., Sci. de la Terre, Géol.-Géophys., IRD-Nouméa, Nouméa, New Caledonia.

Pelletier, B., et al. (2000b), Le seisme d'Ambrym-Pentecôte (Vanuatu) du 26 novembre 1999 (Mw: 7.5): Données préliminaires sur la séismicité, le tsunami et les déplacements associés, C. R. Acad. Sci., Ser. IIx, 331, $21-28$.

Pelletier, B., G. Cabioch, S. Calmant, V. Ballu, and J. Perrier (2004a), Bathymetry of the coastal areas of some islands of Vanuatu, Misc. Rep. 576, SOPAC, Suva, Fiji.

Pelletier, B., G. Cabioch, J.-M. Bore, C. Chauvin, and C. Douglas (2004b), Campagne Terralis-Vanuatu 2003 du N. O. Alis, cartographie multifaisceaux et dragages des zones côtières de certaines îles du Vanuatu central (Sud Pentecote, Est Ambrym, Paama, bancs De Chaulliac, Ouest et Sud Epi, Ouest et Sud Efate), 10-22 décembre 2003, mission report, Sci. de la Terre, Géol.-Géophys., IRD-Nouméa, Nouméa, New Caledonia.

Regnier, M., S. Calmant, B. Pelletier, Y. Lagabrielle, and G. Cabioch (2003), The $M_{w} 7.51999$ Ambrym earthquake, Vanuatu: A back arc intraplate thrust event, Tectonics, 22(4), 1034, doi:10.1029/ 2002TC001422.

Taylor, F. W., C. Frohlich, J. Lecolle, and M. Strecker (1987), Analysis of partially emerged corals and reef terraces in the central Vanuatu arc: Comparison of contemporary coseismic and nonseismic with Quaternary vertical movements, J. Geophys. Res., 92, 4905-4933.

Taylor, F. W., et al. (1995), Geodetic measurements of convergence at New Hebrides island arc indicate arc fragmentation caused by an impinging aseismic ridge, Geology, 23, 1011-1014.
Walder, J. S., and P. Watts (2003), Evaluating tsunami hazards from debris flows, in Submarine Mass Movements and Their Consequences, edited by J. Locat and J. Mienert, pp. 155-162, Springer, New York.

Watts, P. (1998), Wavemaker curves for tsunamis generated by underwater landslides, J. Waterw. Port Coastal Ocean Eng., 124, 127-137.

Watts, P., and S. T. Grilli (2003), Underwater landslide shape, motion, deformation, and tsunami generation, in Proceedings of The Thirteenth (2003) International Offshore and Polar Engineering Conference, Honolulu, Hawaii, USA, May 25-30, 2003, vol. 3, pp. 364-371, Int. Soc. of Offshore and Pol. Eng., Cupertino, Calif.

Watts, P., S. T. Grilli, J. T. Kirby, G. J. Fryer, and D. R. Tappin (2003), Landslide tsunami case studies using a Boussinesq model and a fully nonlinear tsunami generation model, Nat. Hazards, 3(5), 391-402.

Waythomas, C. F., and P. Watts (2003), Numerical simulation of tsunami generation by pryoclastic flow at Aniakchak Volcano, Alaska, Geophys. Res. Lett., 30(14), 1751, doi:10.1029/2003GL017220.

Wei, G., and J. T. Kirby (1995), Time-dependent numerical code for extended Boussinesq equations, J. Waterw. Port Coastal Ocean Eng., 121, $251-261$.

Wei, G., J. T. Kirby, S. T. Grilli, and R. Subramanya (1995), A fully nonlinear Boussinesq model for free surface waves. Part 1: Highly nonlinear unsteady waves, J. Fluid Mech., 294, 71-92.

M. Ioualalen, Institut de Recherche pour le Développement, UR082/ UMR Géosciences Azur, l'Observatoire Océanologique de Villefranchesur-mer, La Darse, B.P. 48, F-06230 Villefranche-sur-mer, France. (mansour.ioualalen@geoazur.obs-vlfr.fr)

B. Pelletier, Institut de Recherche pour le Développement, UR082/UMR Géosciences Azur, B.P. A5, F-98848 Nouméa Cedex, New Caledonia.

M. Regnier, Institut de Recherche pour le Développement, UR082/UMR Géosciences Azur, La Technopôle de Sophia Antipolis, 250, rue Albert Einstein, F-06560 Valbonne, France.

P. Watts, Applied Fluids Engineering, Inc., private mail box 237, 5710 East 7th Street, Long Beach, CA 90803, USA. 